Viso - Cadernos de estética aplicada

Revista eletrônica de estética

ISSN 1981-4062

$N^{\circ} 17$, jul-dez/2015

http://www.revistaviso.com.br/
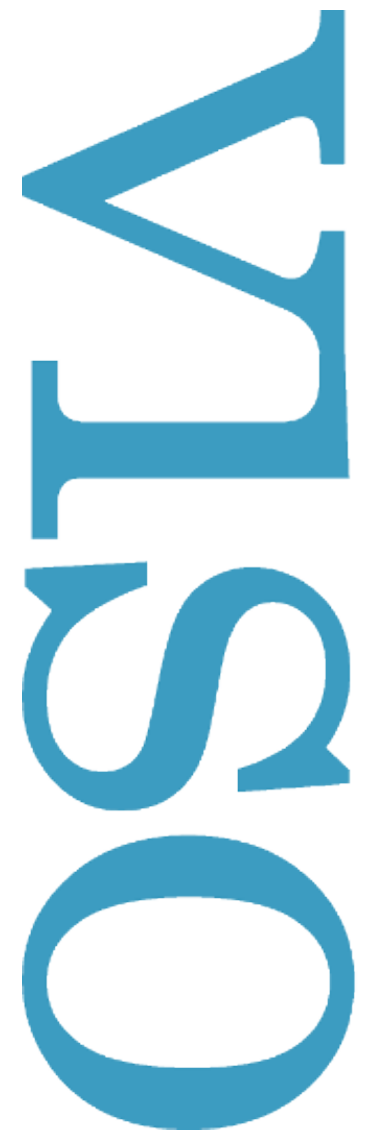

\title{
Desde onde contemplar: sobre o primeiro livro de Franz Kafka Simone Brantes
}




\section{RESUMO}

\section{Desde onde contemplar: sobre o primeiro livro de Franz Kafka}

Ao falar sobre Contemplação, o seu primeiro livro, Kafka diz haver nele uma "desordem sem salvação", que "é preciso se aproximar muito" para ver aí "alguma coisa". Esse artigo é resultado de uma tentativa de aproximação desse lugar ideal de contemplação a partir do qual não apenas podemos ver neste conto "alguma coisa", mas a coisa que está em jogo em uma de suas últimas obras, o conto $A$ construção. Em Contemplação, nos interessará o movimento dos personagens de dentro para fora e de fora para dentro e a fuga ao perigo de alienação que é representado por um outro com um poder aniquilador sempre articulados à busca da autonomia. "A coisa" que está em jogo em "A construção" e em Contemplação será a escrita na qual irão se cruzar, como estados inseparáveis, a autonomia e a alienação.

Palavras-chave: Contemplação - construção - escrita - autonomia - alienação

\section{ABSTRACT}

\section{From Where Contemplate: On Kafka's First Book}

When talking about Contemplation, his first book, Kafka says that there is a "disorder with no salvation" in it, that "it's necessary to get really closer" to see "something" there. This text is result of an attempt of getting closer to this ideal place of contemplation from which we cannot only see "something" in this short story, but the thing that is at stake in one of his last works, the short story The Burrow. In Contemplation, what concerns us is the movement of the characters from the inside to the outside and from the outside to the inside and the escape to the danger of alienation that is represented by an other as an annihilating power always articulate to the quest of autonomy. "The thing" that is at stake in "The burrow" and in Contemplation will be the writing in which the autonomy and the alienation will be crossed as inseparable estates.

Keywords: Contemplation - burrow - writing - autonomy - alienation 
BRANTES, S. "Desde onde contemplar: sobre o primeiro livro de Franz Kafka". In: Viso: Cadernos de estética aplicada, v. IX, n. 17 (jul-dez/2015), pp. 15-44.

DOI: 10.22409/1981-4062/v17i/203

Aprovado: 24.01.2016. Publicado: 27.02.2016.

(C) 2016 Simone Brantes. Esse documento é distribuído nos termos da licença Creative Commons Atribuição-NãoComercial 4.0 Internacional (CC-BY-NC), que permite, exceto para fins comerciais, copiar e redistribuir o material em qualquer formato ou meio, bem como remixá-lo, transformá-lo ou criar a partir dele, desde que seja dado o devido crédito e indicada a licença sob a qual ele foi originalmente publicado.

Licença: http://creativecommons.org/licenses/by-nc/4.0/deed.pt_BR

Accepted: 24.01.2016. Published: 27.02.2016.

(C) 2016 Simone Brantes. This document is distributed under the terms of a Creative Commons Attribution-NonCommercial 4.0 International license (CC-BY-NC) which allows, except for commercial purposes, to copy and redistribute the material in any medium or format and to remix, transform, and build upon the material, provided the original work is properly cited and states its license.

License: http://creativecommons.org/licenses/by-nc/4.0/ 
... existe aí realmente uma

desordem sem salvação, ou antes:

são lampejos claros sobre uma

confusão interminável e é preciso

aproximar-se muito para ver alguma coisa.

Kafka sobre Contemplação

Se os personagens de Kafka nunca chegam, ou se toda chegada aciona um novo partir, se estar no que seria o fim é estar de novo sem forças no começo, experimentar uma junção de partida e chegada numa espécie de ponto morto, no qual cada um desses personagens bate sempre de cara com ele mesmo, se o tempo desses personagens é sempre atemporal - e aqui atemporal é o tempo que se retira a ponto de aquele que nele se sustenta estar sempre quase caindo para fora dele, mal se equilibrando na estreita margem -, se não há nenhuma saída, por que queremos nos apossar disso? Ou seja: por que queremos sentir sobre nós o peso dessa experiência? Talvez porque nessa falta de saída se abra alguma porta, talvez porque esse tempo congelado seja o mais dilatado de todos, porque todas as possibilidades corram sob a sua aterrorizante fixidez. Talvez porque o pesadelo tenha leveza graças a isso que ainda hoje - um pouco envergonhados - chamamos de beleza.

É este dar com a cara na porta que Günther Anders aponta como o aparecimento de saídas em várias direções, como a experiência de uma não limitação: uma fragmentação do peso de um ponto fixo na leveza de vários pontos de fuga. Quando não se tem saída, é fundamental que aquilo que não é saída possa valer como tal. Esta saída ele descreve (não são palavras de Günther Anders) como um cavar na língua dutos sempre abertos, rotas de fuga, como um escapar pela conjunção se. A representação do que se abre é sempre tão precisa quanto se não fosse meramente virtual, é precisa mesmo quando nenhum se pode se sobrepor a outro. Portanto a saída é uma arquitetura.

Nessa arquitetura o poeta está em casa. Ele faz de sua expatriação a própria possibilidade de habitar com plenos direitos. Não pode condenar-se. Ele é a própria abertura da porta. Não chega a um mundo já constituído e fechado. Aí ele não procura, sempre já achou: o seu mundo nasce com ele, ele é o criador, não recebe de alguém as leis. Ele está junto a si mesmo no seu princípio. E aqui, no entanto, se insinua a desconfiança. As paredes da construção estão prestes a desabar a um pequeno sopro. Quando se pergunta desafiadoramente onde agora está afinal de contas Deus, se revela a fragilidade deste que se tornou tão forte. A arquitetura, a construção, é onde aquele que a ergue pode realmente, o mais fundo, ser ferido.

Parece que é isso, esse instante prestes a desaparecer, que é essa construção. Senti-la já parece ser viver o seu desmoronamento como aquele homem que, ao se dar conta de que algo que doía já parece não doer, sente a dor regressando. Esse mínimo limite que separa a construção de seu desmoronamento poderia talvez ser pensado como a 
diferença de forma e conteúdo. O conteúdo é o corpo estranho, o que instaura a diferença entre Kafka, o escritor, e K., o personagem barrado em seu acesso à palavra confirmadora do Castelo. O absoluto é o que carrega aquele que vai despertá-lo para sua realidade limitada, relativa. Trata-se de acordar e ver, de contemplar. O inimigo não está fora, está dentro. Walter Benjamin, que, quando descreve uma passagem de $\mathrm{O}$ castelo, usa sempre o nome Kafka ao invés de K., talvez faça isso a partir desta compreensão. Talvez ele esteja também pensando nesta dualidade de dentro-fora. ${ }^{1}$

Contemplar e acordar são dois verbos aqui entrelaçados. Toda representação tem um conteúdo. No que chamamos de contemplação parece que o que se apresenta é sempre a necessidade de suportar o representado. E neste suportar o representado também perceber a si mesmo como o peso morto de que foi possível se livrar ao representar. $E$ nesse acordar, é um levar a mão ao próprio corpo e perceber-se. Às vezes o artista acorda e percebe-se só como o inseto que sonhou ser artista. Às vezes ele percebe que a sua construção não passa da sua própria vulnerabilidade.

Em sua biografia de Kafka, O mundo prodigioso que tenho em minha cabeça, Louis Begley, para corroborar a sua opinião desfavorável sobre as dezoito histórias reunidas no pequeno volume Contemplação, publicado em 1912, transcreve as instruções que Kafka transmite ao amigo Max Brod pouco antes de morrer sobre o destino a ser dado à sua obra: "As poucas cópias de Contemplação podem permanecer. Não quero dar a ninguém o trabalho de macerá-las; mas que nada desse volume torne a ser publicado". ${ }^{2}$

Kafka tem, como tantos escritores, uma história de títulos. Sugeriu aos seus editores que publicassem juntos, sob o título "Os filhos", "O veredito", "A metamorfose" e "O foguista", modificando o desejo antes expresso de que fossem publicadas junto com "A colônia penal" sob o título "Punições". As sugestões foram defendidas com o argumento de que cada um desses títulos era sustentado pela mesma coerência presente em cada uma das obras em separado. Outro tipo de publicação foi sugerido para "O veredito": um volume em que ele figurasse sozinho cercado em todas suas margens pelo espaço que convém a um poema. Todas essas sugestões são válidas porque de fato elas se amparam no modo de ser dessas obras e o mesmo valeria se ele tivesse sugerido o mesmo amplo espaço de respiração para cada uma delas. No caso de Contemplação para cuja edição nós desconhecemos sugestões, sabemos apenas que Kafka ficou muito satisfeito com a tipografia escolhida pelo editor, pois deu ao livro uma lombada menos magra -, a publicação em separado dos dezoito pequenos textos em prosa - contos ou poemas - daria apenas um grande trabalho de pesquisa ao leitor crítico de Kafka, pois eles dialogam tanto entre si que a "chave" parece se encontrar mesmo em uma reunião que demanda esse título. Talvez, exagerando um pouco, como os textos que compõem O processo e $O$ castelo.

Mas voltemos ao desgosto de Louis Begley e do próprio Kafka. 
Para Günter Anders, toda a narrativa de Kafka já está sempre lá, em um ponto. Ela se revela inteira como em uma fotografia, em uma imagem. Se ela se desdobra, é somente para mostrar essa imagem. E não qualquer imagem, uma imagem que fulmina. Assim a imagem aparece na exposição desse crítico - a partir de uma passagem do próprio Kafka - como o que divide, rasga nossa paisagem em duas: "o raio petrificado". ${ }^{3}$ Ora, se podemos chamar a imagem de raio, é porque podemos exigir da imagem algo. Raio é o que vai direto ao ponto queimando em seu percurso todas as imagens: uma espécie de matéria negativa, que quase deixa no lugar da imagem o puro movimento de ir direto ao seu fim. Mas o que a profusão de imagens de Contemplação parece de algum modo provocar é um retardamento nesse movimento. Se compararmos as últimas obras de Kafka com esse livro de 1912, o que vemos é que estas surgiram a partir de um processo levado às últimas consequências de depuração da própria imagem. Nelas aquele raio finalmente pode encontrar na imagem o elemento de sua propagação.

Segundo Louis Begley, o título "Meu mundo urbano" seria o título de um esboço da primeira grande obra de Kafka, o "Veredito", escrito do dia 22 para o dia 23 de setembro de 1912. "Aparentemente, da noite para o dia, Kafka dominou a arte de contar histórias" ${ }^{\text {, }}$ diz Begley. Mas o que encontramos de mundo urbano em "O veredito"? O conto se passa quase inteiramente dentro de poucos cômodos de um prédio que se alinha a outros prédios "baixos de construção leve" à margem do rio. O exterior - excetuando-se o que é visto da janela por Georg Bendemann e o que aparece nas alusões aos próprios negócios e aos malogrados negócios do amigo "russo" solteirão em Petersburgo aparece apenas no final quando a total transformação do jovem, bem sucedido comerciante prestes a ingressar definitivamente na vida adulta pelo casamento, em filho sentenciado à morte pelo pai provoca a sua saída desabalada do espaço enclausurado em direção à ponte sobre a qual vai saltar cumprindo o veredito do pai como uma prova de amor, "como o excelente atleta que tinha sido nos anos de juventude para orgulho dos pais". Só neste momento a cidade realmente aparece como que abafando por completo a vida privada: "Nesse momento o trânsito sobre a ponte era praticamente interminável". ${ }^{5}$

Nos pequenos textos em prosa de Contemplação, essa relação entre o espaço urbano e o espaço privado da família burguesa - pouco importa se o personagem que tem sobre si o peso de dinamizar as histórias seja na maioria das vezes o solitário, pois sua existência será definida negativamente em relação a esta família - parece mais complexa, pois o movimento aqui deve ser decidido de dentro para fora ou de fora para dentro. Existem distâncias enormes a serem superadas para entrar, como o peito aberto para o abraço do "trapaceiro", à porta da casa para a qual o personagem foi convidado; sair da casa da família à noite quando já sinalizou de vários modos a permanência é quase um feito épico em "O passeio repentino". Aqui todo ato parece um ato de vida e morte, um ato de autopreservação ou de confirmação de si mesmo. Ou talvez mesmo um ato de criação da criatura no princípio dos tempos, pois lendo Kafka sempre temos a impressão de que o mundo está começando, ainda no seu jogo entre o ser e o nada. Em "O desmascaramento de um trapaceiro", o que o personagem encontra como guardiã da 
entrada da sala onde se reúnem os convidados da casa senhorial é a vida totalmente confiante em si mesma, que é solo, que dá sustentação àqueles cujo "refinamento" já os levou para longe da certeza:

Depois subi correndo a escada e na antessala lá em cima os rostos fiéis, tão sem fundamento, dos criados me alegrou como uma bela surpresa. Olhei para todos um após o outro, enquanto eles me despiam o casaco e tiravam pó das minhas botas. Respirando fundo, o corpo aprumado, entrei então na sala. ${ }^{6}$

A palavra alemã traduzida por Modesto Carone como "trapaceiro" é a palavra "Bauernfänger", cujo significado literal, talvez já oculto sob o uso na época de Kafka, é um enredador de camponeses, de homens do campo. Ele é um intrujão, o que se coloca entre o seu interlocutor e seu objetivo, com seu papo furado, com sua conversa mole, que desvia o interlocutor do que tem de fazer para lograr, trapacear. Ou seja: um engana trouxas. A trapaça, no entanto, parece se resumir a deixar o trapaceado sempre no meio do caminho, a ocupar o lugar da pura indiferença. Ele tem algo do demoníaco que prescreve não reconhecer valor em nada, que espalha a morte ao redor e apenas tolera o adormecer numa espécie de mínimo casulo. Se existe metamorfose, ela só pode ser para o animal que não tenha o mesmo sentido de direção que o homem: o animal que tem a natureza, mas não tem mais o mundo. ${ }^{7}$

Mas aqui quem parece estar mais próximo da definição do animal é o Bauer, o camponês. Aos porteiros que não colocam em dúvida a existência parecem corresponder, em "Crianças na rua principal", os homens que chegam sobre suas carroças depois de um dia de trabalho nos campos e riem "que é uma vergonha". ${ }^{8}$ Esse riso que é uma vergonha parece também sinalizar uma completa entrega à vida, que de algum modo confunde interior e exterior, que transforma aquele que assim ri em pura superfície, que parece desfazer ou neutralizar a diferença entre homem e animal, homem e natureza. Outro modo de dizer isso é que os porteiros, os camponeses aparecem aqui como puro em-si sem uma relação com um para si. Se lembrarmos da segunda cena de sexo entre K. e Frieda, descrita em sua animalidade, lembraremos também que são as criadas que, entrando no quarto dos dois sem qualquer cerimônia e os surpreendendo enroscados nus sobre a cama após o ato sexual, introduzem o pudor: na cena de um em si mesmo existe algo que não deve ser para si mesmo e por isso elas jogam sobre eles uma toalha para cobri-los. "Depois as criadas subiram e uma delas disse: - Veja como eles estão deitados. E por compaixão atirou uma toalha sobre eles". ${ }^{9}$ A palavra usada pelo narrador para descrever o ato da criada é compaixão. É difícil interpretar o alcance dessa palavra. Até porque, inserida nesse contexto que tentamos estabelecer, a cena evoca o começo da história cristã do homem. A compaixão aqui é a dor que se sente com, diante da vida totalmente exposta. O que não pode ser visto é o que não pode ser abarcado com os olhos, o que transpõe o limite do olhar. O que é tão em si mesmo que pode ser entendido como segredo e deve ser protegido, resguardado como tal. ${ }^{10}$ 
Friedrich Schiller, cuja vida chega ao fim setenta e oito anos antes do nascimento de Franz Kafka, fala, em Poesia ingênua e sentimental, da perfeição que encontramos na natureza, animais, crianças, nos costumes do povo, nos monumentos dos povos antigos. Em certo momento, eles podem infundir em nós um prazer e uma paz que derivam da concordância que sentimos existir neles com eles próprios. A experiência, portanto, não é estética, e sim a experiência de que eles atingiram tudo que se pode ser no plano moral. Eles são o lugar de uma espécie de um passivo auto-abençoar-se. A moral aqui se resume a uma relação consigo mesmo que não comporta nenhuma diferença; mas o homem é o lugar da diferença, do espaço aberto, da distância desde onde se olha, se contempla algo. E é desde essa distância em relação à natureza que ele deve alcançar a perfeição. A perfeição que deve ser realmente almejada pelo homem é, portanto, aquela que ele atinge pela cultura. É como se devêssemos dizer: é desde a distância, desde a cultura, que deve haver o ser um com a natureza.

Eles são o que nós fomos, eles são o que nós devemos nos tornar. Nós éramos natureza, como eles, e nossa cultura deve nos reconduzir, pelo caminho da razão e da liberdade, à natureza. Eles são, portanto, ao mesmo tempo representação de nossa infância perdida, que nos permanece mais fiel; daí que nos preencham certamente com melancolia. Ao mesmo tempo são a representação de nossa maior realização no ideal, daí causarem uma sublime comoção. ${ }^{11}$

Poesia ingênua e sentimental foi publicado em 1795. Sabemos o quanto esse ideal ficou para trás nos tempos de Kafka. O que se poderia destacar aqui é o fato de que não é um mero camponês que quase cai na lábia do trapaceiro, intrujão, do "Bauernfänger", mas alguém que já chegou à cidade há um bom tempo, já aprendeu a distinguir esses tipos e demonstra vergonha por não ter, por muito pouco, caído na esparrela:

Mas esse sorriso eu já não enxerguei até o fim, pois a vergonha me fez virar de repente. Só nesse sorriso, portanto, eu havia reconhecido que ele era um trapaceiro e nada mais. E no entanto eu já estava nesta cidade fazia meses, julgara conhecer a fundo esses embusteiros...12

Bastante interessante é ainda o fato de que a criança-personagem-narrador de "Crianças na rua principal" e as demais crianças com as quais ela dialoga falam de um modo muito estranho às crianças. "- Por que está suspirando tanto? O que foi que aconteceu? Uma infelicidade especial, para sempre irreparável? Não podemos nunca nos recuperar dela? Está tudo realmente perdido?", diz uma das crianças que recebe o menino que finalmente sai da modorra burguesa da casa da família para brincar com um grupo de garotos na/da rua. Um desses garotos, porém, é o que chama a atenção para o estranho jeito de falar, agora flagrado na fala do menino que sai de casa: "Graças a Deus, finalmente, vocês estão aqui." - "Você sempre chega atrasado!" - "Atrasado, eu?" "Você mesmo, fique em casa se é o que está querendo." - "Não quero concessões." - "O quê? Concessões? Que maneira de falar é essa?"13 
No conto "Passeio repentino", que vem logo na sequência de o "Desmascaramento de um trapaceiro", o movimento é também de dentro para fora, como em "Crianças na rua principal". Mas esse movimento se dá quando não haveria mais nada que chamasse para fora, sendo necessário para isso um grande corte, um corte que se dá contra algo que se opõe, que pesa demasiadamente contra ele. Já se vestiu o roupão, já se deixou ficar sentado à mesa iluminada escrevendo ou jogando - ações que sempre antecedem a decisão de dormir -, o tempo lá fora é totalmente inóspito, as escadas já estão escuras e o portão do prédio já está fechado. Poderíamos dizer então que quem executa esse corte aparece como absolutamente original. Alguém que estabelece uma diferença infinita entre ele e tudo do que ele se afasta ao sair. Quem sai de algum modo nasce de novo, tomando a partir de si mesmo o ponto de partida do seu agir. O que fica para trás, a família, fica totalmente apagada. Sendo ele mesmo o seu ponto de partida, não nascendo dela, mas de si próprio, a família "se desvia rumo ao inessencial". O que sai não tem mais nada senão o que se estende diante de si. E o amigo é o que se mostra como futuro ("Tudo fica mais reforçado quando, a essa hora tardia da noite, se procura um amigo para ver como ele vai"). Mas se este amigo é um futuro aberto, não devemos vê-lo como a meta concreta da chegada do "Passeio repentino". O que é importante é que uma ação concreta colocou o narrador personagem como fonte permanente de todas as suas ações. A ação será sempre ação se desenrolando infinitamente no tempo, movimento contínuo. O que aqui importa no agir é aquele que age se apreender como fonte da ação, identificar-se com ela, e assim compreender a ação como ação em projeto. Ação que mantém aquele que age no horizonte de sua total independência, um agir fora do risco da alienação. E se ele agora tem estatura é porque se ergue a partir de si mesmo ("enquanto, firme de alto a baixo, os contornos com as linhas carregadas, dando uns tapas na parte traseira das coxas, ascende-se à sua verdadeira estatura"). Interessante é esse bater nas coxas como se representasse um primeiro dar-se conta de si mesmo, uma primeira confirmação da sua existência. Bater para apreender os seus "contornos com as linhas carregadas", o que só se pode perceber pela diferenciação, quando se está totalmente à parte dos outros, e não quando se faz parte do corpo da família. ${ }^{14}$

Mas esse ficar radicalmente longe da alienação Kafka descreve, em "Crianças na rua principal", como o predicado essencial dos alienados mentais, pois percebe que há algo nesse contínuo manter-se distante da alienação que é aberrante. O menino é levado adiante pelo impulso de uma ação inicial; e essa ação que já não precisa de uma nova decisão, que vai sempre cada vez mais decidida no embalo de um primeiro ato ${ }^{15}$ é aquela que o leva, no retorno para casa, a desviar o caminho (aberrar) para a lendária cidade do sul da qual alguém Ihe fala em sua aldeia, despertando nele todos os porquês da infância: "Lá existem pessoas - imaginem! - que não dormem!" / "E por que não?" / "Porque não ficam cansadas." / "E por que não?" / "Porque são loucas." / "Então os loucos não ficam cansados?" / "Como é que os loucos poderiam ficar cansados?" 16 
Aberrações são também em Kafka as transformações dos homens em animais. Desde onde, nos perguntamos, esse moto-contínuo rouba aquilo que faz do homem homem? Desde onde ele projeta o homem para o domínio do em-si mesmo da natureza? Desde onde esse moto-contínuo se relaciona com a perda da distância desde a qual o homem se dá conta de si próprio? Interessante é encontrar nessas questões um lugar para a compreensão do movimento, em "Crianças na rua principal", como o que tem como objetivo o encontro da "cova" ${ }^{17}$ suficientemente grande para que se possa deitar nela com espaço suficiente para estender todos os membros.

Como na última valeta seria possível estirar-se ao máximo sobretudo os joelhos - nisso ainda mal se pensava e ficava-se deitado de costas, como um doente propenso a chorar. Piscava-se quando um jovem, as mãos nos quadris, pulava o talude para a rua, sobre nós, com as solas escuras. ${ }^{18}$

Movimento contínuo, ausência da necessidade da de-cisão, de ganhar o separado do si mesmo desde o qual se pode ser homem, desde o qual se ganha sempre a consciência de que é preciso conquistar-se. Ou ainda a compreensão de que se é o aberto no qual tudo pode adentrar para ser o que é, porque o homem em si mesmo não é nada, ele é apenas o que deve suportar, sempre como um vazio, aquilo que é. Assim, movimento aqui sinaliza uma existência entificada do homem e, portanto, o não-homem ou o homem morto.

Em "Decisões", o conto que vem logo depois de "Passeio repentino", trata-se de lutar energicamente contra o movimento, de não sair, em hipótese alguma, da situação de repouso. No começo de "Crianças na estrada principal", ao qual voltamos mais uma vez a partir desse novo conto, há uma passagem extremamente bonita em que a inação, a quase paralisia do menino sobre o pequeno balanço no quintal arborizado da casa dos pais - onde nada parece dar um passo - é contaminada pela contemplação dos movimentos dos pássaros: "Depois os pássaros ergueram voo como se fossem um chuvisco, eu os acompanhei com o olhar, vi como subiram num fôlego até não acreditar mais que eles subiam, mas sim que eu estava caindo...". Uma contaminação que é gradual, pois passa desta simples impressão de movimento próprio ao movimentar-se de fato, que é a princípio um balançar-se que presumimos ser fraco já que a fraqueza do menino é apresentada como a própria motivação do balançar-se ("e segurando firme nas cordas, comecei a balançar um pouco, de fraqueza") para depois tornar-se mais forte "quando o sopro do ar" fica "mais fresco e em lugar dos pássaros em voo apareceram as estrelas trêmulas". ${ }^{19} \mathrm{O}$ vento mais fresco parece corresponder aqui à abertura do espaço para a ação, em contraposição ao ar mais quente que parece pregar homens, animais e até mesmo coisas no chão. Há uma impressão aqui do movimento como resultado de um abismar-se, um perder-se no sem fundo do céu que escurece, e nas estrelas como aquilo que aparece como o mais distante do humano, e mais uma vez uma possível relação com aquela aldeia mais ao sul. 
Em "Decisões" ${ }^{20}$, deve-se evitar o movimento mesmo quando ele é transmitido por algo exterior: "e no caso de se sentir atirado longe por um sopro, não se deixar seduzir por nenhum passo desnecessário". A necessidade desta paralisia está aqui ligada à necessidade de evitar o encontro com o outro, que aqui demanda também um esforço para manter este outro a uma certa distância, distância que se traduz em apenas aguentar o peso que ele representa: "Trabalho contra qualquer sentimento, saúdo A. impetuosamente se ele vier agora, tolero $B$. amistosamente no meu quarto e, a despeito da dor e do esforço, em casa de C. engulo tudo o que é dito em tragos largos". Para Kafka - escritor -, qualquer um é só um outro: a série alfabética aberta - A, B, C mostra que todos podem ocupar esse lugar. Existe Kafka (ou K.) e o outro que o nega. A relação de autoreferência já é aqui uma relação que parte do outro. A pergunta quem sou eu parece ser assim respondida: eu sou aquele que o outro aniquila. Uma relação de autoreferência que pode ser traduzida como alienação: ser definido a partir do outro é já estar aí indefeso, estendido no chão frente a ele para ser pisoteado como uma coisa ou um inseto.

Por isso mesmo, nas "Decisões", os seus contornos (aqueles que aparecem com "linhas carregadas" em "O passeio repentino") se desfazem frente ao outro e ele o deixa, mantido até então a uma certa distância, entrar; pois suas ações que garantem a fronteira deixam de ser armas de defesa confiáveis: "Mas ainda que seja assim, a cada erro, que não pode faltar, tudo - o fácil e o difícil - vai ficar paralisado e eu precisarei girar e voltar ao ponto de partida". ${ }^{21}$

Ora, "decisões" é a tradução de Modesto Carone para a palavra alemã "Entschlüsse", plural de "Entschluss", "decisão", que deriva do verbo "entschließen", decidir-se, resolverse. $\mathrm{Na}$ origem deste verbo, se encontra o verbo "schließen", fechar. "Ent" tem aqui o sentido de afastamento, inversão da ação a qual ele se apõe, como o nosso "des" em "destrancar", "destravar", "descerrar". Logo, "Entschluss", "decisão", "resolução", corresponde em sua origem ao afastar-se do que está fechado, enclausurado, um sair, vir para fora. Quando alguém decide, ele liberta. Quando o personagem de "Partida repentina" decide sair de casa, ele sai justamente para o fora que é o elemento de toda e qualquer decisão. Sua decisão se dá no âmbito da própria decisão. Nesse sentido também, poderíamos entender por que a sua decisão é aquela que, no conto, comporta todas as decisões. Aqui reside a força de decisão: o peito aberto. Decidir nos confronta necessariamente com o domínio público, nossas decisões já nos colocam sempre em contato com os outros, elas revelam a nós mesmo como quem afeta e é afetado por eles. Em toda decisão, também nós nos abrimos.

Não somos um interior fechado, mas aquilo que se mostra sempre que nós realizamos algo e essas realizações se dão sempre num mundo que se define por uma articulação de fazeres. Nossas ações não têm independência das ações dos outros: um mundo público é um mundo em que a ação de um tem implicações sobre as ações do outro. No nosso mundo, uma ação é sempre solidária (ou inimiga) de outra ação. Nossas ações 
podem ser peças numa linha de montagem. Quando agimos, não estamos menos separados do resultado de nossa ação do que o funcionário de seção de uma fábrica. Agimos sem saber a origem e o telos da nossa ação. Não temos a visão do todo: só vemos uma pequeníssima parte dele, que se reduz a um certo imediato, à sobrevivência e aos prazeres e desprazeres da nossa vida doméstica ou social, à realização de alguns sonhos e desejos, e não nos sobra muito tempo para pensar no que escapa a esse urgentíssimo imediato. Estamos ocupados com a necessidade de nos virar nesse, no nosso mundo. "O comerciante", um outro conto de Contemplação, mostra o proprietário de uma pequena loja e sua angústia diante do fato de que depende dos seus fregueses, de que está na mão deles, dos quais está distante, pois pertencem a uma outra classe social. É normal pensar nos negócios e pensar se os fregueses de uma dada classe social terão dinheiro para comprar ou para honrar seus compromissos. Um comerciante que leia, por exemplo, um jornal de economia para se orientar não despertaria o menor espanto. Mas nesse conto a vida dos fregueses invade a vida do comerciante e a rouba. É quase como se ele não pudesse viver sem o controle da vida deles. Na relação de dependência, a vida de um já equivale à vida dos outros. Não existe, na relação de comércio, liberdade para o negociante: "Meu dinheiro está nas mãos de pessoas estranhas; a situação delas não pode ser clara para mim; o infortúnio que poderia atingilas eu não sou capaz de pressentir; como é que poderia evitá-lo? Talvez elas tenham se tornado pródigas e deem uma festa no jardim de um restaurante e outras ainda permaneçam um pouco na festa, na sua rota de fuga para a América". ${ }^{22}$

Em "Mensagem imperial”, de 1916, será um problema lógico; em "O comerciante" é uma questão econômica que se torna um problema existencial. $\mathrm{O}$ narrador personagem de Kafka, tal como o homem do subsolo de Dostoiévski, é o homem da "consciência amplificada". Essa consciência amplificada não limita esse outro ao pai ("Seja como for, éramos tão diferentes e nessa diferença tão perigosos um para o outro, que se alguém por acaso quisesse calcular por antecipação como eu, o filho que se desenvolvia devagar, e tu, o homem feito, se comportariam um em relação ao outro, poderíamos supor que tu simplesmente me esmagarias sob os pés a ponto de não sobrar nada de mim", diz ele em Carta ao pai, talvez um personagem como os fregueses do conto de Contemplação); nem às noivas, destruidoras em potencial de seu projeto literário, no qual está concentrada a sua própria vida, mas ela está sempre aí prestes a incorporar mais alguém na série aberta do abecedário.

Os fregueses aparecem para ele como o "espectro" de que fala em "Decisões": "Por isso o mais aconselhável de fato é aceitar tudo, comportar-se como massa inerte e no caso de se sentir atirado longe por um sopro, não se deixar seduzir por nenhum passo desnecessário, fitar o outro com olhos de animal, não sentir remorso, em suma: esmagar com a própria mão tudo que na vida ainda resta de espectro, ou seja, aumentar a última calma sepulcral e não permitir que mais nada exista fora dela". ${ }^{23}$ 
Cortar o contato com o outro, fechar todas as portas e janelas, qualquer entrada ou saída, viver num mundo só para si mesmo, um mundo cerrado, impermeável, uma fortaleza. O estranho é que o caminho para esse fechamento seja o "aceitar tudo". "Aceitar tudo" do outro como forma de abrir uma distância intransponível entre si mesmo e o outro, "aceitar tudo" do outro como forma de não ser afetado por ele, se tornar tão passivo a ponto de não sentir. Manter o pensamento apenas em si mesmo enquanto sofre a ação de fora. É assim que ele escapa e se torna absoluto. Pela primeira vez independente, encontra em si mesmo o seu próprio princípio. Pela dor, escapa da dor. $\mathrm{O}$ método não é o mesmo, mas, assim como o homem do subsolo, ele quer encontrar em si mesmo a saída, precisa apartar-se de tudo para ser começo. E assim torna-se tão estranho a si mesmo como uma coisa. Essa coisa que se preserva, enquanto de fora sofre ataques de todos os lados, é descrita como uma "massa inerte". Mas essa massa inerte olha o outro com "olhos de animal". Os olhos de animal aqui parecem ser aqueles olhos que olhando aparecem como uma barreira que o olhar de quem é olhado não é capaz de atravessar. No olhar do animal, sempre temos a impressão de cairmos no vago, pois a distância de onde vem esse olhar aparece sempre como o impenetrável. 0 olhar do animal se parece menos com uma entrada do que com a superfície sobre a qual tudo pode apenas flutuar. Também a dor que o animal sente - por maiores e mais imediatos que sejam os sinais da dor - também parece ser sentida desde uma distância. Mas ainda assim resta o espectro ("o que na vida resta do espectro"). Nessa "calma sepulcral", ele ainda se faz ouvir, talvez como um barulho por trás ou por dentro das paredes: um barulho ecoando no total silêncio. É preciso por isso exterminar o invasor, aniquilar quem desafina o silêncio. Parece ser do silêncio que sai o que o perturba, de modo que se busca sempre "a última calma sepulcral", que sabemos não ser nunca a última, pois é exatamente "a última" que é sempre preciso ampliar, "e não permitir que mais nada exista fora dela".

Nesta situação resta apenas um mínimo contato com o corpo, perde-se quase por completo a experiência da corporeidade do homem. Não existe mais aquele corpo que responde sob um toque decidido, um corpo que traduz um movimento em outro movimento, que é corpo no próprio movimentar-se, pura resposta aos movimentos, que encontra no movimento a sua própria afirmação, como no conto "Passeio repentino". Aqui a parte do corpo que toca e a parte que é tocada estão entre as menores: "Um movimento característico desse estado", diz o narrador-personagem no final, "é passar o dedo mínimo por cima das sobrancelhas".

No entanto, os piores espectros, nesse conto, surgem daquilo que ainda não ganhou realização. É quando surge a energia sem direção, quando a partir do puro informe é preciso chegar a uma forma, que eles entram em cena. O trabalho na loja é só uma forma de despachá-los ou, poderíamos dizer a partir das linhas logo acima, uma forma de dar aparência de realizado ao que é informe. O trabalho na loja cria a aparência de uma superfície sobre o que na verdade é abismo. O espectro surge do peso excessivo da necessidade da criar, de tornar perfeito, de perfazer algo. 
Quando pois ao anoitecer de um dia útil a loja é fechada e de repente vejo diante de mim horas nas quais não poderei trabalhar em nome das necessidades ininterruptas da minha loja, minha excitação - despachada de manhã previamente, para bem longe irrompe em mim como a maré que retorna, mas não se detém e me arrasta consigo sem objetivo. $^{24}$

Essa necessidade de criar algo é descrita como um "humor". Talvez o humor seja aqui um vislumbrar à distância aquilo que será realizado. Mas o trabalho na loja já impediu "o uso" desse humor. Já deixou sobre o corpo e a roupa do comerciante uma camada que o afasta da possibilidade desse uso. Ele já o estragou, já o transformou em alguém que é impuro, imperfeito para perfazer algo: "E, no entanto, não tenho de modo algum a capacidade de usar esse humor e só posso ir para casa, pois tenho o rosto e as mãos sujos e suados, a roupa coberta de nódoas e pó, o boné de serviço na cabeça e as botas arranhadas pelos pregos dos caixotes". ${ }^{25} \mathrm{O}$ único totalmente só no seu prédio - e aqui só deve ser entendido no sentido mais radical, como não ter absolutamente nada já dado em que se apegar -, ele encontra os espectros dentro do elevador vazio: "- Fiquem quietos, recuem, querem entrar na sombra das árvores, atrás dos cortinados das janelas, dentro do caramanchão?" ${ }^{26} \mathrm{E}$ o mais abismal vem na sequência, quando ele os convida a olhar pela janela: são os espectros que devem contemplar, é a paisagem urbana que vai aparecer agora nos/por seus olhos. E o conto termina mais uma vez - para quem mantiver na memória o fim de "Desmascaramento de um trapaceiro" - com o encontrar terra firme nos olhos de uma empregada, quando sai do elevador e despacha os fantasmas: "Aí tenho de descer do elevador e mandá-lo de volta para baixo, tocar a campainha, e a empregada abre a porta enquanto eu cumprimento". ${ }^{27}$

Em "Ser infeliz"28, o último e mais longo conto de Contemplação, o personagem se refere aos inquilinos do prédio onde mora como lojistas cuja desocupação, após o encerramento do expediente, faz com que sejam tomados pela necessidade imperiosa de encontrar alguma coisa que os ocupe; por exemplo, intrometer-se pela porta aberta do quarto vizinho se acreditarem que alguma coisa - duas pessoas conversando, por exemplo - está acontecendo. Nessa descrição, podemos ver os lojistas como aqueles que só têm uma existência assegurada encontrando alguma coisa - se alguém joga para eles algo de que devam se ocupar; eles só se perfazem se estabelecem em torno de si próprios aquele contorno em linhas fortes, que aparece em "Passeio repentino", a partir de um outro de fora: são em si mesmos vazios, são fantasmas. Lembram um pouco, se nós vamos dando corda às impressões que o conto desperta, aquela boneca que é tomada como gente no conto $\mathrm{O}$ homem da areia de T. H. Hoffmann. De fato, esse é o único conto do livro cujo clima é de uma história de terror. "Assim são essas coisas. Essas pessoas já deixaram para trás o trabalho do dia; a quem se submeteriam, na liberdade provisória do anoitecer? Aliás, você também sabe disso. Deixe-me fechar a porta". ${ }^{29} \mathrm{O}$ "você" do diálogo é também um fantasma, um fantasma criança que saiu de uma porta que se abriu em uma parede "tão rápido assim porque a pressa era necessária e até os cavalos de tração lá embaixo empinavam no pavimento como animais que, as gargantas expostas, se enfurecem na batalha". ${ }^{30}$ São animais dóceis - 
cavalos de tração, que puxam servis carros e carroças - que se tornam indomáveis, assustadores. Eles também espectros de cavalos.

O conto já começa com o personagem no limite, sem qualquer socorro. Ele retorna a um grito, presumivelmente após uma tentativa de salvação. Essa salvação ou saída parece ser uma janela aberta para a qual ele corre alucinadamente sobre o "tapete estreito como se fosse uma pista de cavalos". Se os cavalos "lá embaixo empinavam", aqui também poderíamos dizer que ele "empina" diante da "visão da rua iluminada" e a passagem ou a saída se mostra barrada. Assim, ele tem apenas o seu próprio horror, aquele que até agora está confinado ao seu quarto. E deste modo a cena volta ao começo, ela vai se repetir infinitamente, e ele vai retornar a um grito que parece esperar por ele. O grito já está lá esperando ser chamado de volta: ele vai gritar para ouvir o grito. O único espaço que se abre, dentro do seu quarto, para o seu grito é o fundo do espelho.

Quando já havia ficado insuportável - perto do anoitecer, uma vez em novembro - e eu corria pelo tapete estreito como se fosse uma pista de cavalos, e assustado com a visão da rua iluminada dava outra vez a volta e na profundidade do quarto encontrava de novo, no fundo do espelho, um alvo recente e gritava só para ouvir o grito, ao qual nada responde e ao qual nada também retira a força do grito, que portanto ascende sem contrapeso, e não pode parar nem mesmo quando emudece [...]. ${ }^{31}$

É claro que o espelho o defronta com o grito, mas parece haver algo a mais na escolha no dentro e não fora dele. O grito é emitido por quem grita e é emitido pelo espelho, é artificial. Não é apenas um grito imediato, é imagem. Não estamos falando de um grito do qual possamos nos apropriar sensivelmente, por isso também ele "ascende sem contrapeso". Só poderíamos nos apropriar dele de refração em refração, de reflexo em reflexo. Em "Ser infeliz", estamos também no terreno da especulação.

É exatamente neste momento - como se fizesse parte desse mesmo elemento onde espera o grito - que se abre uma porta na parede e surge o espectro criança. Após um diálogo, no qual se estabelece uma relação especular entre os dois ("Sua natureza é a minha e se pela minha própria natureza eu me comporto amavelmente com você, então você não pode agir de outra maneira" ${ }^{32}$ ), o narrador sai do quarto como sairia em qualquer outra situação absolutamente corriqueira e encontra um "inquilino do mesmo andar" que, diante da revelação de que saíra por ter um fantasma no quarto, observa com a mesma indiferença que acusa na fala do interlocutor, o que ainda nos deixa mais uma vez no âmbito da relação especular - que este diz isso "com o mesmo desagrado que teria ao encontrar um fio de cabelo na sopa". O diálogo dos dois, que apresenta falas que parecem sempre as faces de uma mesma moeda ou as falas de alguém e do seu reflexo no espelho, serve para colocar diante de nós, esclarecendo-a, a palavra que o vizinho usou para se dirigir ao personagem que deixa o quarto. A palavra traduzida por Modesto Carone como "tratante" não é dessa vez "Bauernfänger", mas "Lump". Tratante só é uma boa tradução se não a entendermos apenas como aquele que trata, combina, 
mas não cumpre, pois ela tem também o sentido de enganador, trapaceiro. Onde o personagem saudado pelo vizinho trapaceia? A resposta está já na afirmação de que o desagrado que ele sente diante de um fantasma se parece com o desagrado que teria com o cabelo na sopa: ele desfaz a distância entre ele e os fantasmas. "- Acha então que eu não creio em fantasmas? Mas de que me serve essa descrença?". "- Muito simples. Você não precisa mais ter medo quando um fantasma vem a você". ${ }^{33}$

A questão aqui é que os fantasmas continuam sendo fantasmas. Não se trata, portanto, do entendimento de que é o nosso medo que alimenta os fantasmas, de que eles só existem onde essas almas crentes demais, sempre dispostas a dar corpo ao que não o tem, abrem espaços para eles. Esses fantasmas não são aqueles que tomam almas fracas. Estamos muito distantes da simplicidade encarnada pelo nosso ditado popular "assombração sabe para quem aparece". Aqui os fantasmas existem e são trapaceados. Mas ainda há alguma coisa por trás dos fantasmas. O personagem afirma ter medo é de algo que não é nomeado, alguma coisa que está antes de toda visão, algo que não é configurado e que aparece como a sua causa. Seria possível perguntar aos fantasmas pela sua causa - como o outro recomenda -, mas isso criaria o risco dos próprios fantasmas se desfazerem, pois eles são frágeis demais. É a própria camada entre o que aparece e a sua causa que está sempre a ponto de se desfazer. Nós acreditamos mais nos fantasmas, ele diz, do que eles acreditam em si próprios. O que significa que essa camada, a mediação da qual falamos, precisa ser continuamente refeita. Precisamos fazer com que novamente os fantasmas acreditem que são reais. ${ }^{34}$

Em uma carta de 1922 endereçada ao amigo Robert Klopstock, Kafka assim fala da retomada da escrita após o episódio de seu colapso nervoso que o levou a uma nova temporada de repouso em Spindlermühle, uma cidade tcheca na fronteira com a Polônia:

depois de ter sido fustigado em períodos de insanidade, comecei a escrever, e esse
escrever é a coisa mais importante do mundo para mim [...] - assim como o delírio é
importante para o louco (se ele o perdesse, 'enlouqueceria') ou como a gravidez é
importante para a mulher. [...] Portanto tremo de medo, protejo a escrita de todas as
perturbações, e não só a escrita, mas a solidão que faz parte dela. ${ }^{35}$

Aqui o escritor está para o louco como a escrita está para o delírio. O louco precisa do delírio para não mergulhar no abismo da loucura, o escritor também precisa da escrita para se manter à superfície, sem a escrita ele não se segura e também cai como o louco na "insanidade". Assim como não sabemos o que é a loucura, sabemos menos ainda o que é isso que está por trás dela. O louco é sempre o louco numa espécie de queda de braço, num enfrentamento da própria loucura. Sua loucura é sua produção, como a escrita é a produção do escritor: ela é o modo como algo obscuro se torna de algum modo claro para ele. Algo se organiza para um e para outro na escrita e no delírio, da escrita e do delírio surge algo em que eles se apegam. Tanto o escritor como o louco, portanto, têm o seu mundo. E eles dependem visceralmente desse mundo porque dele depende a sua sobrevivência. Por isso - porque sem essa mediação da escrita ele 
mergulharia na insanidade que o ameaça com o aniquilamento -, Kafka diz ter tanto medo e proteger a escrita de todas as perturbações. E também que protegê-la é proteger a solidão que faz parte dela. ${ }^{36}$

O trecho citado foi lido pela primeira vez como uma citação da biografia de Kafka escrita por Louis Begley. A fonte de L. Begley foi a tradução inglesa das cartas de Kafka a amigos. No original, a palavra para delírio é "Wahn", que retoma a palavra que entra na composição de "períodos de insanidade", "Wahnsinnszeiten". "Wahn" pode ser traduzido, entre outras palavras, por "delírio", “ilusão", "alucinação". "Wahnsinn”, por "demência", "insanidade". A palavra "Wahn" tem atrás de si um longo período de formação até entrar no século XVIII no campo semântico que, com o tempo, vai limitar a sua tradução imediata àquele campo ao qual pertence a palavra "delírio". ${ }^{37}$ Mas por ora gostaríamos de deixar o que podemos ganhar ao acompanhar a formação e evolução semântica da palavra para mais tarde. Nesse momento, seria interessante pensar a partir do infinitivo latino "delirare", que significa literalmente afastar-se do traço alto de terra deixado pelo arado (lirā) e por extensão, de modo figurativo, se desviar da linha reta, do caminho certo e corrente. Um dos significados fornecidos para "delirare" pelo Dictionnaire LatinFrançais de F. Gaffiot ${ }^{38}$ é "extravaguer", de onde surge "extravagant". Nós temos, no português, tanto o verbo quanto o adjetivo, "extravagar" e "extravagante". "Extravagar" é um verbo que, se um dia foi usado correntemente, já caiu no esquecimento. Mas, se formos verificar o seu significado em um dos bons dicionários de língua portuguesa, verificaremos que ele tem uma rica diversidade de significados cuja articulação em um todo nos parecerá aqui necessária: "1. Encontrar-se fora da ordem, do número etc.; 2. apresentar-se solto, separado de um conjunto; 3. deixar-se dominar por divagações; 4. encontrar-se perdido, sem caminhos ou soluções" ${ }^{39}$ O significado de "extravagante", que no nosso uso corrente, tem um sentido mais limitado, sai também ampliado a partir dos vários significados desse verbo dicionarizado apesar do desuso. "Vagar" já significa, num uso corrente, um ir a esmo, sem rumo, vagabundear. No dicionário de latim-francês, encontramos para "vagarī" também o significado de "flutuar", que nos faz pensar nas bolinhas de sabão às quais Robert Musil comparou Contemplação. É impossível deixar de reconhecer neste livro "lírico" de Kafka um clima urbano captado pelo olhar do flanêur baudelairiano. Há sempre uma visão de instantâneos, dos recortes fotográficos, que captam garotas que viajam no trem, a passante com o rosto parcial e, em seguida, totalmente iluminado pela luz do sol, os carros ou a rua iluminada vista pela janela, os homens que se cruzam nos passeios noturnos, casas abertas para reuniões sociais, passeios com grupos de amigos ou excursões "burguesas" às montanhas. Assim, "extra" acrescentaria à palavra uma intensificação; extravagar, um vagar para além dos limites que poderiam circunscrever o vagar. O prefixo "extra" tem também os significados para os quais a palavra "extravagar" nos lança: "fora, além, por fora". ${ }^{40}$

Em seu livro Kafka: pro e contra, Günter Anders nos diz que Kafka está trancado por fora. O opressivo para ele é encontrar um muro na entrada do mundo. Kafka não entra no mundo para julgar o que é o mundo. Ao homem do subsolo de Dostoiévski, de que 
nos ocupamos na primeira parte deste ensaio, é vedada a experiência comum de confiança no mundo. Ele tem uma percepção, uma consciência amplificada que o leva a colocar esse mundo em questão: o mundo para ele é uma brincadeirinha de criança, que sempre que, apresentando-se a ocasião, ele destrói como um adulto que pusesse abaixo um castelinho de areia. Não há além dessa nenhuma ação possível porque qualquer ação demandaria um fundamento que iria recuando indefinidamente até um último inalcançável fundamento. O seu exílio no subsolo é absolutamente necessário porque ele quebra um trato essencial que garante a comunidade. A comunidade precisa de homens naturais e ele é o homem que "nasceu na proveta". ${ }^{41}$ Mas como vimos ele é vingativo: viver no subsolo, no lugar abjeto, é o modo como ele se afirma, o modo como ele se apropria da dor para fazer da dor a sua dor, para dominar, para estar antes da fonte da dor. Basta na dor mostrar a sua careta retorcida de homenzinho mal e zombeteiro para triunfar sobre ela. O que o homem do subsolo faz é maltratar a própria dor, produzindo um canto que é o seu deboche da própria dor que sente: ele a supera acrescentando, lá pelo terceiro dia, aos gritos que ela desperta o seu canto de vingança. A palavra canto, usada, em um dos primeiros capítulos da primeira parte do romance, põe a literatura em primeiro lugar no âmbito da proveta, do artifício do qual nasce o homem do subsolo, ou seja, a mostra desligada da vida, e em segundo lugar, a faz instrumento do espírito de vingança. ${ }^{42}$ Mostramos como uma possível diferenciação que se insinua entre o personagem e o escritor Dostoiévski no fim do romance mostra que essa é a literatura do homem do subsolo; mas uma vez que a literatura foi ligada ao antinatural, ao elemento inimigo da vida, jamais poderíamos sair do romance sem pelo menos uma pulga atrás da orelha.

Kafka, em resposta a uma pergunta de seu amigo Max Brod, diz que há "esperança suficiente, esperança infinita - mas não para nós". ${ }^{43}$ Quem ele engloba nesse nós? Essa é uma pergunta que tentaremos enfrentar mais tarde. Se seguirmos Günter Anders, afirmaremos que para ele a ausência de salvação decorre da impossibilidade de entrar no mundo. Não entrar no mundo: não ser orientado por direções. Mundo é o que oferece sentido a partir daquilo que se faz dentro do mundo. E é preciso estar inserido numa ordem a partir da qual se abra algum fazer. É preciso pertencer e neste pertencer estar lançado em um fazer, um agir. Qualquer "teoria" só pode surgir desse estar imerso nesse ocupar-se com nossos afazeres. E é nesse afastamento do mundo - no ganhar a distância desde onde se ganha a visão - que aparece tematizado em nosso horizonte essa ligação com o mundo. A pergunta sempre será o mundo é mundo desde onde? Que caminhos se abrem dentro do nosso mundo para que possamos, percorrendo uma distância, olhar esse mundo que ficou para trás? Que Kafka tenha uma igual compreensão de que o sentido surge de um ser aí, de que ele se apresenta num ser com os outros, num estar já situado numa ocupação, num fazer parte do mundo, estar dentro dele como um pertencer-Ihe está exposto em um dos aforismos de Zürau: "A palavra ser [sein] significa duas coisas em alemão: estar aí [Dasein] e pertencer-lhe [lhm gehören]". ${ }^{44}$ Claro, Kafka não usa a palavra mundo, mas sim ser. Mas de onde vem "ser" para Kafka? A afirmação do personagem K. em $\mathrm{O}$ castelo - a possibilidade de dizer eu sou - 
depende da possibilidade de ser aceito na comunidade como agrimensor. Enquanto não é aceito, não há mundo. Enquanto não há mundo, tudo que poderíamos chamar de ser se perde na imprecisão do absurdo. A aldeia do Castelo é um embaralhamento das direções, um ataque à medida, contra as quais a função do agrimensor se opõe. A aldeia é uma confusão como o caos. Ela é o antimundo, o antes do estabelecimento da ordem a partir da qual o ser é o ser. Os personagens que surgem do antimundo são personagens antinaturais: são às vezes esboços quase se desfazendo como esses personagens de névoa dos quais fala Benjamin ${ }^{45}$ ou personagens que se embaralham, se confundem com outros personagens, são deformados, pois não existem as desejadas relações de espaço para delimitar com perfeição os seus corpos. Lembremo-nos dos dois ajudantes e da mulher do dono do Albergue da Ponte, imensa no quarto mínimo. É do antimundo também que surge o tribunal que condena previamente o ser ao não ser: Joseph K. é sacrificado antes de entrar no mundo.

Mas é evidente que Kafka já está em um mundo. Tem família e relações familiares, seu presente na família tem um fundo de passado: é filho de um pai que saiu do campo para vir morar na cidade; que, se urbanizando, deixou o estreito círculo da comunidade judaica, que trocou as relações pautadas pelos costumes e pela religião dessa comunidade pelo modo de viver mundano de Praga, que então encarnava, mais de perto, a vida sob o domínio do Império austro-húngaro. E seu enraizamento nesse mundo vai mais longe. É por parte de pai bisneto de um açougueiro ritual, neto de um avô que começa modestamente os negócios que, levados a um nível superior pelo filho, garantirão a prosperidade da família e o "refinamento" que a afastará tanto da "mesquinha" e "tosca" vida dos judeus do campo quanto do antissemitismo mais flagrante dos camponeses tchecos. Por parte de mãe, sua vida está enraizada em condições econômicas e sociais mais favoráveis, pois a família de Julie Löwy está uma geração à frente da dos pais de Herman Kafka. ${ }^{46}$ Também, pelo menos em sua idealização, os antepassados da mãe o ligam a um ambiente religioso e cultural bem mais refinado:

Em hebreu meu nome é Amschel, como o avô materno de minha mãe, de quem ela, que tinha seis anos, quando ele morreu, se lembra como um homem muito devoto e erudito [...]. Ainda mais erudito do que o seu avô era o bisavô de minha mãe. Cristãos e judeus o honravam igualmente. Durante um incêndio, ocorreu um milagre graças à sua devoção: as chamas pularam sua casa, enquanto as casas ao redor foram destruídas pelo fogo. ${ }^{47}$

Não existe evidentemente a vida de Kafka sem ser filho, sem ser filho de quem é, sem ser estudante de uma escola alemã num país em que a língua do povo é o tcheco e a língua das repartições públicas e da cultura erudita dos círculos germanófilos é um alemão "desprovido da força de raiz profunda de uma língua própria" ${ }^{48}$, sem ser aluno de uma faculdade de direito, advogado, ao longo da vida, de duas grandes firmas de seguros, amigo de Max Brod, Franz Werfel, Robert Klopstock, noivo por várias vezes sem chegar a casar-se, "amásio" de Dora Diamant, praticante de natação, vegetariano, 
simpatizante da Antroposofia, diagnosticado com tuberculose, paciente, interno de sanatórios, fotógrafo, desenhista, estudante de hebraico, flanêur, boêmio, frequentador de teatros e bordéis, turista, missivista...escritor.

E, no entanto, Günter Anders nos apresenta Kafka sem mundo, sem esse vínculo essencial que garante o estar no mundo, sem esse pertencimento que garante para alguém a experiência da consistência de um mundo. Se, porém, é evidente que Kafka é alguém de um dado mundo, a experiência é necessariamente a do corte com o seu mundo, a experiência da fragilidade de todos os laços estabelecidos com ele, de um pertencimento que se desfaz. Se lermos Carta ao pai, perceberemos como Herman Kafka é apresentado como pai que questiona a sua condição de filho. O tempo inteiro Kafka lê a si mesmo nas atitudes e palavras do pai como aquele que não fez por merecer essa filiação. $O$ esforço do pai foi grande demais para que este aceite the dar o que foi conquistado de mão beijada. Ele deve provar a condição de filho pelo trabalho, essa condição só pode ser assegurada pelo seu sacrifício. Ele tem que pagar esse tributo ao pai. Essa é a condição de pertencer à família: assumir o sofrimento dos antepassados. A própria condição de ascensão social que dá ao filho a condição de escolher uma profissão liberal ou se tornar um intelectual ou escritor o coloca como o seu inimigo. Ele é o parasita, o que rouba o seu sangue. Está sempre pronto para ser expulso como um estranho. Em $\mathrm{O}$ veredito ele aparece como o filho que ocupa o lugar de outro, o filho escolhido, o amigo russo. Toda sua vida - tudo que ele poderia realizar como bem-sucedido homem de negócios, marido, pai de família - é condenada pelo pai. No conto toda a sua vida se torna uma vida irrealizada. A sua vida inteira parece estar confinada entre a condenação do pai e o ato de se jogar sobre a ponte em direção ao rio. Ele morre quando nasce, já é um não ser, um não filho há muito tempo. Em Metamorfose, essa alienação do filho em relação ao pai e, sob seu poder, em relação a toda família, poderia ser expressa como a sua transformação em inseto. Ao mesmo tempo, ela serve para mostrar que a própria família não é capaz de suportar o monstruoso que decorre do corte da ligação com a família. O que a família vai ganhar aos poucos, em Metamorfose, é a força moral para banir definitivamente esse monstro. No fim a família se recompõe, fecha essa fenda que foi aberta em seu corpo. O que se joga para fora é exatamente o que impede o fechamento do círculo familiar, o círculo por onde o sangue da família pode seguir seu curso.

Para os tchecos ele é alemão e judeu, ou tanto faz, pois dá no mesmo; para os alemães ele é judeu. Para os tchecos ele fala alemão, para os alemães não fala o alemão, mas um alemão que eles têm dificuldade em ouvir como alemão. Para tchecos e alemães, ele é judeu, mas não é judeu para os judeus do Leste, que ele reconhece na trupe de teatro ídiche, para ele representante dos genuínos judeus. Ele é advogado, mas não consegue ser advogado porque é escritor, é escritor, mas não consegue ser escritor porque é advogado. Para as noivas ele é visto como marido, mas não consegue se tornar marido. 
Assim Kafka está em um mundo e então um vazio se abre em torno dele. Todas as ocupações, relações, que limitam, que nos indicam o espaço em que nossa vida pode se situar, se retraem e só permanece a indiferença. Esse momento é também o da experiência de uma totalidade, porque o mundo não se apresenta quando nos ocupamos de algo dentro dele, mas justamente quando se retira absolutamente. Kafka sabe o que é o mundo porque subitamente não tem mundo; mas se ele não tem mais a experiência concreta de coisas concretas dentro do mundo, ele tem a experiência daquilo de que tudo é feito, da substância de tudo. E essa substância aqui é o absurdo, esse deserto não habitado por coisa alguma, esse aberto que, não dando limites aos seus possíveis seres, dá espaço para seres deformados, para a mulher do dono do Albergue da Ponte ou para o inseto de Metamorfose. Tudo que existe no mundo de Kafka surge dessa enormidade do todo. Esse é o peso que ele carrega. O peso que ele carrega é o mundo vazio, não relativizado por cada uma de suas criaturas. E esse mundo é como uma disposição, um humor a partir do qual se dá a sua criação.

Heidegger, em Ser e tempo, nos apresenta o temor, o pavor e a angústia como experiências que abrem para nós o mundo em sua totalidade, a mundanidade do mundo. Todos nós, se levados de roldão por essas experiências, somos lançados no abismo quando vemos tudo que nos rodeia recuar para dar espaço ao que é a totalidade que abarca tudo. O que significa que justamente o acesso ao todo sempre implica essa compreensão de estar perdendo tudo, justamente o que é fundamento nos lança no abismo. Mas para Kafka, se acompanhamos corretamente Günter Anders, o mundo inabalável parece ser acessível apenas para os escolhidos. Kafka poderia dizer: nós não entramos no mundo, ficamos barrados às portas dele. Ele está ali e, no entanto, infinitamente inalcançável. Fomos, desde o princípio, distinguidos com o signo da maldição, não somos dignos de entrar nele. Podemos apenas girar em torno dele como renegados.

O mundo está aí, só não podemos entrar nele. Só os abençoados têm esse direito. Quem são os abençoados? São aqueles que têm uma confiança absoluta, aqueles cuja simplicidade equivale à pureza. São os homens que não são artificiais, desenraizados, são aqueles que estão entregues completamente à natureza. Aqui parecemos retornar ao pecado original, ao pecado do conhecimento. Lembremos dos criados à porta do salão em "Desmascaramento de um trapaceiro": eles encarnam a inexistência da dúvida, uma existência em estado de perfeição. E são eles, portanto, que dão passagem, eles permitem através deles a entrada no "céu". Mas como voltar a este momento anterior ao conhecimento? A tentativa de se aproximar dos judeus do Leste, de aprender hebraico, de se aproximar do movimento sionista e talvez até o gosto pelo naturalismo estão sempre ligados - é o que nos parece depois de todo esse caminho - a uma tentativa de se juntar àqueles aos quais parece ter sido franqueada a entrada no mundo, ou seja, no paraíso. Quando Günter Anders diz que para Kafka o aquém é o além parece ser isso que ele está querendo dizer. 
O homem do subsolo sabe que o mundo em que se encontra, o mundo ao qual tem acesso, é o único mundo. Ele poderia como qualquer outro viver neste mundo em comum, mas há algo que de repente o retira do grupo ao qual pertence por vários vínculos como o nascimento, a pátria, a língua, a religião. Ele passa a não pertencer por si mesmo a esse grupo, a tomar distância em relação a ele, a vê-lo como um grupo formado por pessoas tão obtusas como animais. O seu conhecimento o priva de qualquer mundo possível, vai como que fatiando esse mundo de conhecimento em conhecimento até não sobrar nada. Aqui o mundo também é puro vazio, indiferenciado. Nesta falta de limites definidos, os personagens de Notas do subsolo têm o aspecto distorcido característico também dos personagens de Kafka. ${ }^{49}$ Também não existe o Além porque o seu conhecimento é tão ampliado que atinge o próprio fundamento que garante Deus. Ele sente inveja do homem de ação direta, mas ele é também o que nele desperta o asco: o fundamento que estar no lugar desse homem daria a ele não deixa em nenhum momento de aparecer como um fundamento falso, o fundamento que é alcançado pelo verme mais asqueroso. Então se ele não pode chegar ao paraíso, ao Além, nem através do homem de ação direta nem através de Deus, ele precisa chegar a ele por si mesmo. Por si mesmo significa garantir a si mesmo como princípio, como alguém que pode se colocar no princípio sem ser alcançado pela dor que um outro mais poderoso impõe a ele. Quer chegar a um lugar desde onde possa dizer ao que o flagela: aqui você não me alcança, não me golpeia. Faz isso impondo a sua subjetividade, acrescentando à dor a sua parte: a sua careta má e zombeteira. É emporcalhando a dor que ele pretende escapar dela. O homem aqui se torna todo-poderoso pelo espírito de vingança.

Em uma carta a Milena Jesenká, também Kafka parece apontar na direção da possibilidade de se tornar senhor da dor que outro lhe causa, mas, assim como Dostoiévski parece sinalizar em relação ao seu personagem, ele revela este senhor como pura passividade: ele é assujeitado exatamente no momento em que aparece como sujeito. $\mathrm{O}$ amo o usa como seu instrumento. "O animal arranca o látego ao homem e flagela-se a si mesmo, para converter-se em amo, sem saber que isso somente é fantasia produzida por um novo nó na correia do látego do amo". ${ }^{50} \mathrm{Assim}$, em Kafka, não há um sujeito que acredita poder se fazer absoluto, pelo menos não no sentido do homem do subsolo, como último estágio de uma metafísica da subjetividade. Mas talvez haja um lugar em que nada o atinja, um lugar em que ele está sozinho consigo mesmo e no qual o que pudesse estar lá fora se ouviria dentro como puro silêncio, algum lugar no qual ele não dependeria de nenhum outro, um lugar que ele garantiria por si próprio, em que ele nasceria sem qualquer intermediário, apenas a partir de si mesmo. Em suma um lugar onde ele não precisaria perguntar pelo fundamento do que é, pois o que é nasceria com ele, onde ele não seria uma criatura, mas o criador.

Aqui a contraposição entre amo e servo equivale à contraposição entre homem e animal, aquele que não tem mundo, que vive no aberto, no indiferenciado, com o olhar perdido. Não há nenhum ponto fixo capaz de nesse aberto direcioná-lo. O homem ao contrário foi agraciado pelo seu mundo com um sentido. Em "Relato para uma academia", o macaco 
tem de se tornar homem, imitando, macaqueando um mundo. Aquilo que ele não sabe ele deve imitar atravessando uma distância infinita, tão infinita quanto aquela que o mensageiro tem de percorrer com a carta do imperador em "Mensagem imperial". Assim por essa ponte ele entra nesse mundo humano, pois não existe possibilidade de estar no mundo senão pela mediação. Se podemos ver Kafka na figura de "Pedro, o vermelho", podemos dizer que ele se liga aos homens como um artista. E sua arte consiste em mostrar como do não mundo ele cria o acesso ao mundo. O que o macaco artista expõe para os espectadores no teatro é essa ponte. Vejam como eu, o macaco, sei pular para dentro do seu mundo. E ele está mostrando isso na mais extrema solidão, totalmente exposto, nu, sem pelos, como em determinado momento aparece $\mathrm{O}$ animal de "A construção".

Kafka se insere no mundo como artista. A sua arte é a mediação que ele - como "o animal" da passagem citada - pode estabelecer com os homens. O mundo de Kafka é uma espécie de intermediário entre o aberto e o distante mundo humano, é uma ponte de acesso. Mas essa ponte vale em si mesma, ela é o único mundo que ele tem, é nesse mundo que ele pode instalar-se. O trecho da carta a Klopstock em que Kafka estabelece uma relação na qual o delírio está para o louco assim como a escrita está para o escritor - delírio e escrita salvam um e outro do abismo, ou seja, dão a eles um solo, um mundo intermediário no qual habitar - deve nos ajudar a pensar que mundo é esse que estabelece o contato entre o animal e o homem, o mundo que situa Kafka no mundo dos homens como artista, o que sabe fazer a passagem, criar a mediação.

Partimos da palavra alemã "Wahn", à qual dissemos que iríamos voltar, e através da palavra "delírio" chegamos à palavra "extravagar", com seus múltiplos significados, que acreditávamos poder articular: "1. Encontrar-se fora da ordem, do número etc.; 2. apresentar-se solto, separado de um conjunto; 3. deixar-se dominar por divagações; 4. encontrar-se perdido, sem caminhos ou soluções".

O poema "O passageiro", do livro Contemplação, mostra até que ponto pode ir o desenraizamento de Kafka, este "apresentar-se solto, separado do conjunto". Nele a insegurança do seu lugar no mundo afeta aquilo que por si só deveria valer como verdade. O estar no mundo socialmente ("no mundo, nesta cidade, na minha família") contamina o ser. Aqui até o mais concreto se esvai, o concreto deixa de ser uma espécie de superfície, de continente estável sobre o qual se constrói tudo mais. Não existe esse mundo concreto, como não existem, em Ser e tempo, as dimensões de tempo e espaço concretas, matemáticas, abstratas na experiência de um ser aí no mundo. ${ }^{51} \mathrm{O}$ ser depende do mundo, é definido por ele; sem pertencimento ao mundo tudo à nossa volta se esvai. São as nossas relações dentro do mundo que dão consistência a tudo. Abstraia o seu mundo e veja à sua volta as coisas! Isso - Heidegger e Kafka dizem, cada um a sua maneira - é impossível. A ideia de ser é decorrente, é ultrapassada no tempo, pelo pertencer ao mundo. Ser: estar aqui, estar sentada à mesa, sobre a qual há um livro, um monitor, um teclado, qualquer dessas coisas em si mesmas não faz o menor sentido. Por 
isso o primeiro parágrafo do poema "O passageiro" é exatamente assim:

Estou de pé na plataforma do bonde e totalmente inseguro em relação à minha posição no mundo, nesta cidade, na minha família. Nem de passagem eu seria capaz de apontar as reivindicações que poderia fazer, com direito, na direção que fosse. Não posso de modo algum sustentar que estou nesta plataforma, que me seguro nesta alça, que me deixo transportar por este bonde, que as pessoas se desviam dele ou andam calmamente ou param diante das vitrines. É claro que ninguém exige isso de mim, mas dá no mesmo. ${ }^{52}$

Estando ou não afirmado o ser ou o não ser desses seres, estados e ações, o fato é que tudo foi enunciado na escrita, e não só tudo como também a afirmação e a negação que diz respeito a tudo. A escrita se abre à sua potencialidade, ela se encontra desligada do ser concreto e aberta a todas as possibilidades. E é exatamente na língua que temos o ser atravessado pela sua negação. É um pouco como em "Excursão às montanhas", onde se diz: "Se ninguém vem é porque de fato não vem ninguém". Aqui se ganha a possibilidade de afirmar o ser a despeito do não ser. Porque basta que ninguém - aquele que nega a existência de alguém - ocupe o lugar de sujeito que caberia a alguém ou a alguma coisa para que ele ganhe um conteúdo. Ninguém é alguém tanto em "Se ninguém vem" quanto em "é porque de fato não vem ninguém". Aqui não parece apenas se colocar um jogo lógico, mas a possiblidade da escrita de trazer por si mesma algo à luz. E assim no terreno da linguagem é que se forma o grupo de ninguéns que faz uma excursão às montanhas de tal modo que é considerado um milagre que não se dê aquilo que seria a consequência natural no fim de tão curiosa excursão: "Nas montanhas os pescoços se libertam. É um milagre que não cantemos". ${ }^{33}$

Em "A janela da rua" ${ }^{4}$, fala-se de quem vive isolado e gostaria de encontrar o amparo de um braço humano. Esse braço humano parece abrir a possibilidade de experiências: "a mudança das horas do dia, das condições climáticas, das relações profissionais e coisas dessa natureza". O braço humano é aqui o que parece colocar "o só" 55 no mundo. Mas aqui será necessária uma janela: "ele não vai levar isso [a procura por um braço humano] adiante por muito tempo sem uma janela de rua". É do contemplar que sai a força irresistível que impulsiona para o encontro humano: "chega perto do parapeito, não quer olhar para fora e inclina a cabeça para trás, então certamente os cavalos lá embaixo o arrastam no seu cortejo de carruagens e rumor e com isso, finalmente, ao encontro da concórdia humana". As coisas devem ser vistas e nesse ver devem aparecer de tal forma que transmitam ao que contempla a força de se mover na direção dos homens. Pelo aparecer se dá o movimento. Em "Crianças na rua principal", o movimento também encontrava inicialmente seu princípio no olhar. Como fazer as coisas do mundo transmitirem essa força? No poema, não é o olhar que dá às coisas o princípio do movimento que impulsiona quem olha para a concórdia humana. Não se transmite às coisas movimento que por sua vez as coisas transmitem ao transmissor, não existe essa cadeia de transmissão: o movimento em curso, esse movimento que é carregado de potencialidade. Em "Crianças na rua principal" os garotos produziam um movimento e 
depois apenas se deixavam levar por ele. Aqui não: o que está lá embaixo tem força o suficiente para mover alguém na direção do mundo a despeito do olhar, que se desvia quando a cabeça é inclinada "um pouco para trás". Mas tudo neste livro é Contemplação, a palavra que lhe serve de título. Contemplar é olhar com atenção, transmitir às coisas uma tensão a partir da qual elas se tornem princípio de movimento. A literatura em Kafka é um motor. A força que ele não retira do enraizamento no mundo ele tira dela. É também nesse sentido que ela é um medium entre ele, o só, e o mundo, ela faz a ligação, ela é a ponte que ele pode atravessar para o mundo, conquanto que mantenhamos claro para nós que essa ponte se reduz a ela mesma. Nunca se dá a travessia completa. O seu mundo será sempre literatura.

Em "Excursão às montanhas", o movimento acontece também, como vimos, por força da linguagem. E é pela força da linguagem que se estabelece o conviver com os outros. Pela linguagem um ninguém se une a um ninguém que se une a um ninguém... $E$ entre esses ninguéns o espaço que isola se torna mínimo, apenas uma fenda. Existe, portanto, uma total comunhão ou aquela concórdia da qual fala a "Janela da rua". Só esses ninguéns se tornam capazes de fazer tudo realmente juntos. E talvez porque o movimento de negação seja exatamente aquele que pode dar a todos um meio comum. Só ele pode mostrar que estamos ligados sem apelo. Na medida em que somos revelados como o mesmo que os outros, somos revelados como ninguém. E é isso que somos quando estamos na linguagem. Na linguagem se revela algo superior a cada alguém que implica retirar o seu conteúdo particular. Na linguagem, todos, cada um é revelado como ninguém, o que significa exatamente estar indissoluvelmente ligado ao outro. $\mathrm{O}$ escritor aqui é aquele que abre espaço para o comum, porque é no medium que um só fio - o da negação - pode atravessar todos os alguéns. Aqui, portanto, temos um só corpo, um mundo completo, nos encontramos unidos na nossa origem. Kafka se assegura pela linguagem que a ligação não precisa ainda ser buscada, porque ela já aconteceu antes mesmo da separação. Assim essa completude deveria ser expressa nesta altitude da montanha - pelo canto: o elemento comum que atravessa tudo que seja enunciado nele.

A língua como lugar da potencialidade é aquilo que Günther Anders localiza no uso por Kafka do "se", do hipotético. Quando não há um ponto de paragem fixo, Kafka abre caminhos marginais em torno dele. Ele constrói artificialmente uma morada. Uma morada com imensos corredores, labiríntica, por onde se pode entrar e sair, onde não se pode estar senão em movimento. Essa morada está sempre se refazendo, nunca está pronta. Todos os "cômodos" servem para uma rápida parada. Se se constrói algum cômodo central, logo se revela a necessidade de continuar a construção. Todo cômodo por mais central que pareça o é apenas de modo provisório. Assim, voltando à definição de "extravagar", podemos articular os seus sentidos entendendo que o "solto do conjunto" precisa errar sem fim, divagar. Isso é apenas o que ele pode construir para si: lugares potenciais, não reais, de morada. 
Um poema que ilustra esse construir dutos em torno de um ponto inacessível é "Aqueles que passam por nós correndo", um dos mais bonitos de Contemplação. Nele o narrador vê uma cena, mas a verdade dessa cena lhe escapa, ele está muito cansado para abrir espaço para que essa cena entre em seu campo de visão como uma cena claramente definida. $E$ isso apesar de todas as evidências. Ele caminha e a cena se passa bem a sua frente, totalmente diante de seus olhos, pois a rua por onde um homem vem correndo com outro atrás dele sobe à sua frente. $\mathrm{O}$ sentido da cena já está decidido: a cena também se move em linha reta. Pode-se afirmar que o homem de trás persegue um bandido, pois o homem que vem atrás vem gritando e o outro homem que tenta fugir à frente ocupa, por sua roupa esfarrapada, o lugar do marginal. Alguém poderia dizer: a possibilidade de fixar assim a cena deriva de uma interpretação. Mas o que aqui nos importa é exatamente o que está socialmente fixado, a possibilidade de, enraizado em um mundo, interpretar as coisas de um determinado jeito, qualquer que seja. Aqui o narrador vai mostrar que não pode se concentrar em algo, que ele só é capaz de se dispersar em vários sentidos, vários sentidos que ele propõe para a cena. Num determinado ponto, o da convivência social, o sentido está fixado, mas em Kafka os sentidos se proliferam em torno do sentido fixo. Eles abrem um espaço de moradia. Então o narrador está cansado e deixa que o perseguido fuja, apesar de sua fraqueza.

Ele Ihe dá espaço para a escapada. Aquele espaço que ninguém dá ao fraco e esfarrapado ele dá. Porque ele mesmo é fraco, poderíamos dizer, porque o cansaço dissolve a fronteira, o impede de barrar com o limite do sentido preciso. É a partir daí que são propostas várias interpretações para a cena, nenhuma pior ou melhor que as outras. A verdade da cena está aqui, ali e acolá. $O$ interessante é justamente a multiplicidade e não a unicidade. Se não fosse possível a mobilidade, não haveria interesse algum para nós. Perdemos a fixidez, mas ganhamos vida. Ganhamos um conjunto de sentidos, cada um negando o outro e ao mesmo tempo se mantendo em seu direito de se afirmar. É aqui que se encontra a abertura para contemplar: a perspectiva em si mesma.

Pois é noite e não podemos fazer nada se a rua se eleva à nossa frente na lua cheia e além disso talvez esses dois tenham organizado a perseguição para se divertir, talvez ambos persigam um terceiro, talvez o primeiro seja perseguido inocentemente, talvez o segundo queira matar e nós nos tonássemos cúmplices do crime, talvez os dois não saibam nada um do outro e cada um só corra por conta própria para a sua cama, talvez sejam sonâmbulos, talvez o primeiro esteja armado. ${ }^{56}$

Cabe ainda dizer por fim que a palavra "Wahn", traduzida como delírio, tem, segundo a filologia, uma relação que nos pareceu essencial, no que diz respeito aos escritos de Kafka, que é a relação - já não evidente no uso corrente, pois muito antiga - com o verbo "wohnen" (morar), "erarbeiten" (realizar, conquistar com o suor do rosto), "erreichen" (atingir, alcançar), "befriedigen sein" (estar satisfeito). Em segundo lugar, que relendo a afirmação de Kafka sobre Contemplação que está citada no começo deste texto ("existe aí realmente uma desordem sem salvação, ou antes: são lampejos claros sobre uma confusão interminável e é preciso aproximar-se muito para ver alguma 
coisa"), o que já enxergamos nesta obra é já uma das últimas novelas de Kafka, $A$ construção. A análise dessa novela a partir de algumas questões de Contemplação que tentamos aqui tornar evidentes (o movimento constante que se alterna entre sair e entrar, sempre a partir de uma radical decisão; a alternância entre movimento e inércia, o moto contínuo, a insuficiência de qualquer espaço central, a defesa e a vulnerabilidade, a relação com o outro como o que representa o aniquilamento, o canto que surge a partir da instabilidade de um conteúdo assegurado) aparece como o desdobramento necessário do que aqui se conquistou.

\section{bibliografia complementar}

CARONE, M. Lição de Kafka. São Paulo: Companhia das Letras, 2009.

DAVID, C. (org.). Kafka. Themen und Probleme. Göttingen: Vandenhoeck \& Huprecht in Göttingen, 1978.

DELEUZE, G.; Guattari, F. La litterature mineur. Paris: Les éditions du minuit, 1975.

PUCHEU, A; TROCOLI, F. (orgs.). "Dossiê Franz Kafka”. In: Revista Cult, n. 194, 2014.

PUCHEU, A. Kafka poeta. Rio de Janeiro: Azougue, 2015.

\section{* Simone Brantes é doutoranda em letras pela UFRJ.}

${ }^{1}$ BENJAMIN, W. "Franz Kafka. A propósito do décimo aniversário de sua morte". In: Idem. Magia e técnica, arte e política. Tradução de Sergio Paulo Rouanet. São Paulo: Brasiliense, 1996.

${ }^{2}$ BEGLEY, L. Franz Kafka. O mundo prodigioso que tenho na cabeça. Tradução de Laura Teixeira Motta. São Paulo: Companhia das Letras, 2010, p. 177.

${ }^{3}$ ANDERS, G. Kafka: pró e contra. Tradução de Modesto Carone. São Paulo: Cosac Naify, 2004, p. 77.

${ }^{4}$ BEGLEY, L. Op. cit., p. 177.

${ }^{5}$ KAFKA, F. "O veredito". In: Idem. Essencial Franz Kafka. Tradução de Modesto Carone. São Paulo: Companhia das Letras, 1998, pp. 29-42.

${ }^{6}$ Idem. Contemplação/Foguista. Tradução de Modesto Carone. São Paulo: Companhia das Letras, 1999, p. 16.

${ }^{7}$ Günter Anders, em Kafka: pró e contra, chama a atenção para afinidade de concepções de Kafka e Heidegger na compreensão de ambos de que, para o homem, não existe natureza, mas apenas mundo. Este trabalho vai ao encontro desta observação do autor em vários momentos. Ver op. cit., p. 125.

${ }^{8}$ KAFKA, F. Contemplação/Foguista. Op. cit., p. 9.

${ }^{9}$ Idem. O castelo. Tradução de Modesto Carone. São Paulo: Companhia das Letras, 2008, pp. 5859.

${ }^{10}$ É também a vergonha que aparece em O que resta de Auschwitz, de Giorgio Agamben, como um meio pelo qual o sujeito se dá conta de si mesmo. Também o desconcerto que Freud, em $O$ estranho, diz ter sentido ao ser flagrado por algumas mulheres no erro (o errar o caminho e retornar ao mesmo ponto várias vezes) parece equivaler a um estar nu, remetido àquilo de que 
não conseguimos jamais nos desembaraçar e, portanto, parece também ser uma forma radical da experiência da subjetividade, de um ser para si. AGAMBEN, G. O que resta de Auschwitz. Tradução de Selvino J. Assmann. São Paulo: Boitempo Editorial, 2008. Freud, S. "Das Unheimliche". In: Idem. Gesammelte Werke: psychoanalytische Studien + theoretische Schriften + Briefe. E-Artnow, 2015 (Edição Kindle - posição 71080-71089).

11 SCHILLER, F. "Über naive und sentimentalische Dichtung”. In: Idem. Philosophische Schriften. Leipizig: Insel Verlag, s/d.

12 KAFKA, F. "Desmascaramento de um trapaceiro". In: Idem. Contemplação/Foguista.Op. cit., p. 15.

${ }^{13}$ Idem. "Crianças na estrada principal”. In: Ibidem, p. 10.

${ }^{14}$ Idem. "Passeio repentino". In: Ibidem, pp. 17-18. Há uma passagem do Diário de Kafka, citada por Begley, que vale a pena ler com esse conto: "Por vezes esse laço de sangue também é alvo do meu ódio, a visão da cama de casal em casa, os lençóis usados, as camisolas de dormir cuidadosamente postas à vista podem exasperar-me até a náusea, podem virar-me do avesso; é como se eu não houvesse nascido de uma vez, nascesse continuamente no mundo rançoso saído da vida rançosa naquele quarto rançoso, como se realmente precisasse buscar a confirmação de mim mesmo ali e estivesse ligado de maneira absoluta a toda aquela abominação, em parte, se não de todo, pelo menos ela ainda me tolhe os pés, que querem correr e ainda estão grudados na polpa informe original" (Op. cit., p. 31).

${ }^{15}$ Ibidem: "Corremos juntos, mais perto uns dos outros, alguns estenderam as mãos aos demais, não se podia manter a cabeça suficientemente alta porque o caminho era uma descida. Alguém deu um brado de guerra de índio, sentimos nas pernas um galope forte como nunca, nos saltos o vento nos suspendia pelos quadris. Nada poderia nos deter, estávamos numa corrida tal que mesmo na hora de ultrapassar éramos capazes de cruzar os braços e olhar calmamente em volta".

${ }^{16}$ Ibidem, p. 13.

${ }^{17}$ A palavra inicial é Straßengraben que significa valeta à margem de uma estrada. A palavra Graben que entra na composição da palavra junto com Straße (rua, estrada, avenida) significa cova, vala, valeta e se relaciona evidentemente com Grab (sepultura). É impossível não considerar que Kafka que, depois de usar a palavra composta Straßengraben, usa a partir de então apenas Graben, traz à tona - premeditadamente ou não - o sentido de cova.

18 Ibidem, p. 11.

19 Ibidem, pp. 9-10.

${ }^{20}$ Idem. "Decisões". In: Ibidem, p. 19.

${ }^{21}$ Ibidem, p. 19.

${ }^{22}$ Idem. "O comerciante". In: Ibidem, pp. 22-24.

${ }^{23}$ Idem. "Decisões". In: Ibidem, p. 19

${ }^{24}$ Idem. "O comerciante". In: Ibidem, pp. 22-23.

${ }^{25}$ Ibidem, p. 23.

${ }^{26}$ Ibidem.

${ }^{27}$ Ibidem, p. 24.

${ }^{28}$ Idem. "Ser infeliz". In: Ibidem, pp. 37-42.

${ }^{29}$ Ibidem, pp. 38-39.

${ }^{30}$ Ibidem, p. 37. 
${ }^{31}$ Ibidem, p. 37.

32 Ibidem, p. 40.

${ }^{33}$ Ibidem, p. 41.

${ }^{34}$ Interessante que Robert Musil compare as histórias de Contemplação a bolas de sabão. Nas bolas de sabão, o que separa o exterior e o interior vazio é uma finíssima camada prestes a se romper. A passagem citada encontra-se na página 41 de "Ser infeliz".

${ }^{35}$ Carta a Klopstock de 1922. Apud BEGLEY, L. Op. cit., p. 161.

${ }^{36}$ Nenhum conhecimento especializado sobre a "loucura" fundamenta o que se disse aqui sobre a relação entre o louco e o escritor, o delírio e a escrita. O que se tentou foi interpretar, ou melhor, especular a partir das palavras de Kafka em sua carta ao amigo Robert Klopstock.

37 Ver o verbete „Wahn“ no DWDS - Digitales Wörterbuch der deutschen Sprache. (http://www.dwds.de/).

${ }^{38}$ GAFFIOT, F. Dictionaire Latin Français. Paris: Hachette, 1934.

${ }^{39} \mathrm{http}: / / w w w . a u l e t e . c o m . b r / e x t r a v a g a r$

${ }^{40}$ GAFFIOT, F. Op. cit., p. 491.

${ }^{41}$ É essa monstruosidade que ele esconde no subsolo. Para a comunidade, ele é um monstro e os monstros só podem viver no subsolo ou, como Gregor Samsa em Metamorfose, na reclusão burguesa do apartamento dos pais. Mas, se são vistos, são eles a sentir a maior dor, pois, aos olhares de fora, eles se percebem nus, sem os outros como aqueles que, dispostos em torno deles, Ihes oferecem a cobertura para o seu corpo, a sociedade que os veste. Gregor como o inseto visto pela mãe no meio da parede com o ventre colado ao vidro do retrato com a moça toda vestida em peles é apenas a imagem de alguém flagrado na sua absoluta nudez.

${ }^{42}$ Este ensaio foi concebido como um ensaio intermediário de um tríptico; vem após um ensaio sobre a novela de Dostoiévski Notas do subsolo (ou Memórias do subterrâneo) e é seguido por um ensaio sobre os contos "A construção" e "Na construção da muralha da China". Tentamos mostrar na primeira parte que o homem do subsolo, humilhado, maltrata a própria vida para separar-se dela colocando-se como fundamento, começo absoluto. As edições disponíveis em língua portuguesa são: DOSTOIÉVSKI, F. Notas do subsolo. Tradução de Maria Aparecida Botelho Pereira Soares. Porto Alegre: L\&PM Pocket (s. d. na edição Kindle) e Idem. Memórias do subterrâneo. Tradução de Boris Schnaiderman. São Paulo: Editora 34, 2000.

${ }^{43}$ A fala de Kafka é relatada por Max Brod como uma fala que se contrapõe a um comentário seu em uma conversa. Kafka diz: "Somos [...] pensamentos niilistas, pensamentos suicidas que surgem na cabeça de Deus”. Ao comentário que Max Brod faz como uma consequência necessária dessa fala (Deus seria então um "demiurgo perverso e o mundo [...] seu pecado original") Kafka contrapõe essas palavras: "Oh não, [...] nosso mundo é apenas um mau humor de Deus, um de seus maus dias." A resposta citada neste ensaio é uma resposta à pergunta que então é feita por Max Brod: "Existiria então esperança fora desse mundo de aparências que nós conhecemos?". BENJAMIN, W. Op. cit. pp. 141-142.

${ }^{44}$ KAFKA, F. "Aforismos”. In: Franz Kafka Essencial. Op. cit., p. 196.

${ }^{45}$ Usamos aqui a expressão de Benjamin "personagens de névoa" sem desconhecer o fato de que o autor a usa em sentido diferente daquele que nos interessa aqui.

${ }^{46}$ Louis Begley aponta na sua biografia de Kafka um desenvolvimento da situação econômica e social dos judeus que, do século XIX ao começo do século XX, se dava em geral ao longo de três gerações. Esse esquema corresponde perfeitamente à evolução das condições econômico-sociais do avô paterno de Kafka até o neto. "Um novo paradigma judaico estabeleceu-se na Bohemia: avós ortodoxos nascidos na primeira metade do século haviam ganhado a vida com dificuldade 
como comerciantes, mascates, artesãos ou albergueiros em vilarejos e cidades pequenas, às vezes, mas nem sempre, em um gueto; graças ao trabalho incansável, seus filhos prosperaram no ramo de comércio e gravitaram para Praga ou cidades maiores, buscando melhores oportunidades e fugindo do ódio que a população rural tcheca lhes devotava. A segunda geração preservou as formas da prática religiosa judaica, mas o judaísmo já não constituía o fato central de suas vidas. Os netos, ainda mais distanciados da observância religiosa, ingressavam em uma das profissões liberais ou levavam o negócio da família a um nível mais elevado. É claro que nem todos os filhos aproveitavam a oportunidade de enriquecer. Alguns se tornavam escritores" (Op. cit., p. 19). O nome Herman era grafado propositalmente pelo pai de Franz Kafka com apenas um ene.

47 Ibidem, pp. 21-22.

${ }^{48}$ Citação do ensaio de Schleiermacher sobre "Os diferentes métodos de traduzir": "Certamente, porém, estes discursos não procedem do domínio em que os pensamentos brotam com a força de raiz profunda de uma língua própria, senão que são como brotos que um homem engenhoso faz crescer, sem terra alguma, sobre um pano branco." Usamos a tradução do ensaio de Schleiermacher de Celso Braida publicada na revista Princípios, v. 1, n. 21 (jan-jun, 2007), pp. 233265. Disponível em http://www.principios.cchla.ufrn.br/arquivos/21P-233-265.pdf.

${ }^{49}$ Menos a prostituta que parece indicar um caminho para o homem do subsolo de superação da dor a partir de um outro fundamento.

${ }^{50}$ Kafka faz na carta a Milena uma citação do seu aforismo 29 (Kafka, F. "Aforismos". Op. cit., p. 193). A carta a Milena é citada por Begley (p. 185 de sua biografia de Kafka).

${ }^{51}$ HEIDEGGER, M. Ser e tempo. Petrópolis: Vozes, 1988, pp. 134-137.

${ }^{52}$ KAFKA, F. "O passageiro". In: Idem. Contemplação/Foguista. Op. cit., p. 28.

${ }^{53}$ Idem. "Excursão às montanhas". In: Ibidem, p. 20.

${ }^{54}$ Idem. "Janela da rua“. In: Ibidem, p. 34.

${ }^{55}$ A única forma de nomeação do destinatário da carta do imperador em "Mensagem imperial" é "o só".

${ }^{56}$ Idem. "Os que passam por nós correndo". In: Ibidem, p. 27. 